Henslow has no reference to Beccari's remarks which appeared in 1884 in the second volume of "Malesia" under the head of "Piante ospitatrice." In the preface to the descriptions of his exceedingly beautiful and wellknown myrmecophilous plants, Beccari puts forward the very view taken by Prof. Henslow, both with regard to floral and extra-floral nectaries, so that Prof. Henslow has no need "to venture to go further" (i.e. than Beccari), and attribute the large honey-pits at the base of the leaf-stalk of Acacia sphorocephala-see p. I57-to the mechanical irritation of ants.

The book closes with some remarks on the origin of species and the origin of flowers. There is evidence that the author has not thoroughly acquainted himself with some of the literature to which he refers, and in certain instances important references are omitted altogether.

\section{THE CORAL REEFS OF THE PENINSULA OF} SINAI.

Die Korallenriffe der Sinaihalbinsel, geologische und biologische Beobachtungen. Von Johannes Walther, Dr. Phil, und Privat-docent an der Universität Jena. Des xix. Bandes der Abhandlungen der Mathematischphysischen Classe der Königl. Sächsischen Gesellschaft der Wissenschaften. (Leipzig : bei S. Hirzel, 1888.)

N UCH has been written and said of late on the 1 origin of coral reefs; yet the best authorities, when they have not theories of their own to uphold, are agreed in thinking that the matter is far from being finally settled. For this reason a thorough examination of all coral districts is much needed, and every work which adds to the general stock of knowledge on the subject deserves attention. The present memoir deals with the geology of the peninsula of Sinai, and the dependence of the coral reefs in the Gulfs of Suez and Akabah on the characters of the rocks forming the shores. Herr Walther has undertaken difficult and disagreeable, if not dangerous, journeys in the course of his research, and in point of thoroughness his observations leave little to be desired. Believing that a solution of the question in any given area can only be obtained by carefully studying the relations of the reefs to their basis, he has thoroughly examined the geological character of the western mountains of the peninsula, and gives in the first part of the book a full account of all that he observed. The results of his geological survey are most conveniently studied in the plate giving a series of sections through the peninsula. These show that south of Uâdi Firan there are two parallel lines of granite mountains, running north-west and south-east, and between them lies a basin filled in with sedimentary rocks. As far south as Gebêl Nakûs the granite forms the shore, and the author points out that in this region there is no. fringing reef and no coral of any kind. Further south, where the sedimentary rocks form the sea-cliff, the fringing reef makes its appearance, sending out offsets from the shore from place to place, which form barrier reefs and even atolls. The shores of the Gulf of Akabah are granitic, and are devoid of coral reefs. Commenting on this, the author explains that the granite is rapidly weathered out, and that its surface thus constantly undergoing destruction does not afford a sufficiently firm basis for coral growth.
The coral reefs are divided into living reefs, subfossil reefs, and ancient reefs. The first are the fringing and barrier reefs or atolls actually being formed beneath the sea-level; the second are upheaved reefs, lying just above the sea-level, and consisting of coral heads cemented together; the third are infrequent, and consist of masses of dolomitic limestone, the structure of which betrays its coral origin, lying 230 metres above the sea. The thicknesses of these reefs were accurately determined, and were found to be, for the ancient reef, I 5-I7 metres; for the sub-fossil reef, 3-5 metres; and for the fringing reef, 3 metres. These facts are by far the most important part of the author's work; they prove that considerable changes of level have taken place since the coral reefs were first formed, and that these changes have been in the direction of elevation. Thus another instance is added to the many now accumulating of barrier reefs and atolls being formed in an area of elevation. The slight thickness of the reefs also deserves attention. At the end of the book the author speaks of a reflux of the sea having occurred rather than an upheaval of the land. As he does not explain what he means by a reflux of the sea, his statements are rather puzzling. Does he hold the view that considerable changes of sea-level have occurred as consequences of glaciation at either pole? In any case, the phenomenon which he seeks to account for by an alternating level of the sea, viz. the existence of a dead reef below the sea-level and beneath the living fringingreef at Râs Muhámmed, requires for its explanation nothing more than a period of subsidence following on a period of elevation; and several of the geological facts seem to point to a recent though slight subsidence at the southern end of the peninsula.

The author adds nothing to our knowledge of the biological conditions and the composition of coral reefs. His accounts of the living coral and its mode of growth, of the filling up of the interstices of dead coral blocks with detritus, and the formation of oolitic granules, are familiar to all visitors to coral lands, and have been fully described by previous authors. Although an unnecessary amount of space is devoted to the description of these well-known phenomena, the whole work demands the attention of geologists and of students of coral formations. The numerous plates and woodcuts render the text light and easily comprehensible, and the map showing the condition of the coral reefs at different geological periods is of especial interest.

G. C. B.

\section{OUR BOOK SHELF.}

The Book of the Lantern. By T. C. Hepworth, F.C.S. (London: Wyman and Sons, 1888).

THE lantern has of late years become such an important aid to almost every branch of education, even in theological and political matters, that no apology is needed for the publication of a thoroughly practical treatise on everything connected with it. As a former lecturer at the Royal Polytechnic Institution, and present lecturer at the Birkbeck, Mr. Hepworth has gained the practical experience the benefits of which he now places at the disposal of others.

After brief reference to the history of the lantern, the optical arrangements are considered, and these are 